\title{
В.Д. Москалюк
}

\section{ГРИП У ВАГІТНИХ І ПОРОДІЛЬ : НАВЧАЛЬНИЙ ПОСІБНИК / ЗА РЕД. В.П. МАЛОГО, В.С. КОПЧІ. - ХАРКІВ : ФОП БРОВІН О.В., 2020. - 96 c.}

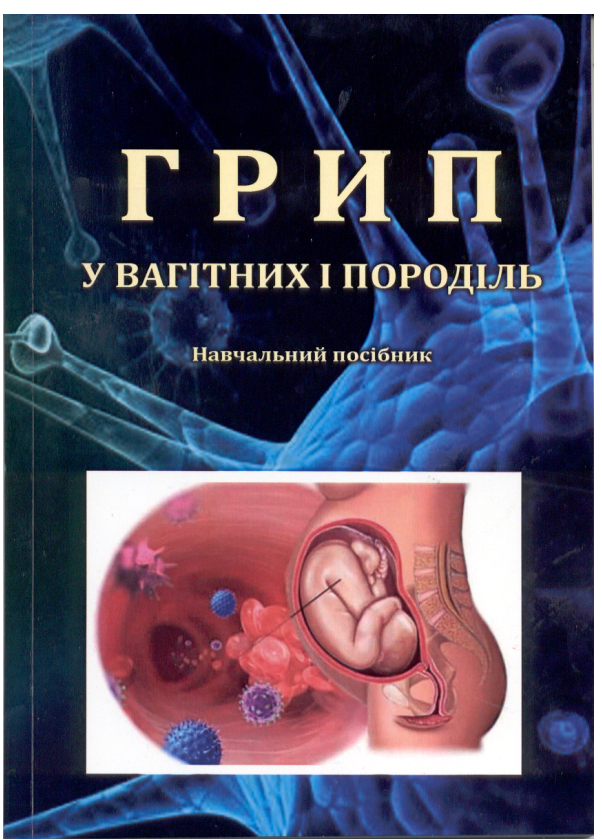

Як відомо, грип нині є наймасовішим інфекційним захворюванням в усіх країнах. Щорічно під час епідемій грипу хворіє до 10 \% населення, а під час пандемій число інфрікованих осіб може досягати 50 \%. За даними ВООЗ, у всьому світі щорічні епідемії грипу супроводжуються розвитком приблизно 3-5 млн випадків тяжких форм захворювання і близько 250 000-500 000 випадків смерті.

Через гормональні та фрізіологічні зміни, що відбуваються у період вагітності, в разі виникнення грипу такі жінки схильні до більшого ризику розвитку ускладнень. На підставі епідеміологічних даних, за останні декілька десятиліть фрахівці ВООЗ включили вагітних у групи ризику розвитку тяжкого/ускладненого перебігу грипу. За даними метааналізів, що враховують тільки лабораторно підтверджені випадки захворювання грипом у період останньої пандемії, встановлено, що хворі на грип вагітні потребують ушпиталення в 4 рази частіше, ніж невагітні; найтяжче грип перебігає у пацієнток в III триместрі вагітності; більше 8 \% госпіталізованим вагітним (переважно в III триместрі) необ- хідна інтенсивна терапія; показник летальності від грипу серед пацієнток в III триместрі вагітності максимальний і досягає 16,9 \%; передчасні пологи у таких жінок трапляються в 3 рази частіше, а перинатальна смертність у 5 разів вища.

До вакцинації, як найефрективнішого профрілактичного заходу щодо грипу, особам, які планують вагітність, слід вдаватися ще перед початком епідемії. У той же час, незважаючи на рекомендації ВООЗ стосовно регулярної вакцинації вагітних, єдиної думки з цього питання немає.

Нині вплив вірусів грипу, особливо H1N1/pdm09, на перебіг вагітності та її наслідки в доступній літературі висвітлений недостатньо, дані роздрібнені, інколи суперечливі, що пов'язано з труднощами антенатальної діагностики, багатофракторною дією інфрекції на плід, відсутністю чіткої кореляції між ступенем тяжкості грипу та інших ГРВІ у матері й ступенем ураження плода, неоднозначним підходом до проведення діагностичних і лікувально-профрілактичних заходів у вагітних і новонароджених. Тому вже давно визріла потреба систематизувати усі накопичені на сьогодні дані в межах одного видання, де конкретно було б висвілено особливості грипу у вагітних, його вплив на вагітність і плід, лікування таких хворих і надання їм акушерської допомоги.

Тож цьогоріч побачив світ навчальний посібник якраз і присвячений цій важливій проблемі. У ньому знайшли відображення короткі відомості про збудника, його морфологію, антигенну специфічність і мінливість, епідеміологічні особливості, патогенез, патологічну анатомію та імунітет. Важливо відзначити, що автори опираються не тільки на численні літературні дані, але й наводять свої відомості, зокрема унікальні фрото макро- і мікропрепаратів та їх описання.

Важливе місце відводиться клініці сезонного і пандемічного грипу. Тут знову ж таки матеріал ілюстрований показовими авторськими рентґенограмами та фото, що неминуче привертає увагу читача та яскраво унаочнює матеріал.

Окремий розділ висвітлює ускладнення грипу у вагітних і патологію вагітності й плода. Так, фрізіологічні зміни 
в організмі, які відбуваються при вагітності, сприяють ризику розвитку ускладнень при виникненні респіраторних вірусних захворювань взагалі. Адже при вагітності зменшується легеневий резерв, потреба в кисні зростає на 15-25 \%, а фрункціональний залишковий резерв легень зменшується. Хвилинний об'єм збільшується на 1,5 л/хв. Після перших 10 тиж вагітності збільшується частота серцевих скорочень і об'єм крові під час систоли. Крім того, імунний статус у цієї категорії людей має тенденцію до зниження. Різко змінюється фрункція ендокринної системи. Тому вагітні жінки є групою високого ризику не тільки до самого інфрікування, але й до серйозних ускладнень грипу, що нерідко закінчуються трагічно. Причиною цього $є$ як вірус A (H1N1)pdm09, так i, хоча й рідше, вірус грипу A (H3N2) чи B.

Слід зазначити, що ступінь тяжкості хвороби, який суттєво впливає на частоту ускладнень, зростає пропорційно до строку вагітності, тому в III триместрі частіше реєструються ускладнення і тяжчий ступінь інфекції. Це може досягати в окремих спостереженнях понад 1800 хворих на 10 тис. вагітних. При доношеній вагітності у захворілих на грип також частіше відзначаються ускладнення при пологах, на відміну від вагітних, які не хворіли на грип. Представлені дані про зв'язок грипу у вагітних в ранніх термінах з аномаліями розвитку новонароджених.

Враховуючи те, що сімейні лікарі, інсекціоністи та акушери-гінекологи, які надають допомогу вагітним, повинні чітко розрізняти ознаки грипу, адекватно оцінити тяжкість загального стану та можливий ризик для здоров'я вагітної, плода/новонародженого/немовляти, суттєве значення мають адекватні методи діагностики грипу у вагітних і рекомендовані клінічні дослідження. Цьому присвячений окремий розділ посібника, який також вирізняється наочними ілюстраціями.

Лікування вагітних і породіль описано за традиційною схемою: базисна, етіотропна, патогенетична та симптоматична терапія, антибактерійне лікування. Акушерська тактика визначається індивідуально для кожної вагітної залежно від ступеня тяжкості захворювання. Попри це, необхідно відзначити, що автори не поділяють усталеного погляду на ураження легень при грипі як грипозну пневмонію, а притримуються оригінального тлумачення такої па- тології як токсичного геморагічного набряку легень, тобто гострого респіраторного дистрес-синдрому. Таке твердження змушує переосмислити й лікування зазначеної категорії хворих, адже зміщує акцент з етіотропної на першорядну патогенетичну - протинабрякову терапію. Практика підтверджує правильність саме такого підходу.

Насамкінець обговорюється профрілактика грипу. Безперечно, чільне місце тут належить специфічній вакцинопрофілактиці як поза, так і під час вагітності. Разом з тим, автори не оминули не менш важливу й ефективну постконтактну хіміопроорілактику.

Укладаючи навчальний посібник, автори розраховували як на студентів старших курсів вищих навчальних медичних закладів III-IV рівня акредитації і лікарів-початківців, так і на досвідчених колег: інфекціоністів, акушерів-гінекологів, лікарів загальної практики і сімейної медицини, терапевтів, педіатрів, науковців. У рамках одного видання звичайно важко охопити всі аспекти порушеного питання. Разом з цим, такий посібник безперечно суттєво допоможе фрахівцям поглиблено вивчити клініку, діагностику, терапію та профрілактику грипу у вагітних і породіль, можливі ускладнення хвороби та вагітності.

\section{Відомості про автора:}

Москалюк Василь Деонізійович - д. мед. н., професор кафедри внутрішньої медицини та інфекційних хвороб вищого державного навчального закладу України «Буковинський державний медичний університет»; e-mail: vdmoskaliuk@ukr.net

ORCID ID: https://orcid.org/0000-0001-6206-1210

\section{Information about the author:}

Moskaliuk V.D. - MD, Professor of Internal Medicine and Infectious Diseases Department, Higher State Educational Establishment of Ukraine «Bukovinian State Medical University»; e-mail: vdmoskaliuk@ukr.net

ORCID ID: https://orcid.org/0000-0001-6206-1210

Конфрлікт інтересів: немає.

Author has no conflict of interest to declare.

Отримано 18.02.2020 р. 